\title{
SOCIAL EXCLUSION AND CHURCH IN THE EXPERIENCES OF KOREAN MIGRANT FAMILIES IN CHRISTCHURCH
}

\author{
Carolyn Morris, Richard Vokes, Suzana Chang
}

\begin{abstract}
This article documents the experiences of new migrant families from South Korea to Christchurch, New Zealand. It is an empirically derived account of these experiences based upon research conducted in Christchurch between March and April 2006 which was funded by the Families Commission/Komihana a Whanau. In this paper we detail Korean migrant accounts of social exclusion and harassment and explore how Koreans make sense of, and respond to, these experiences. ${ }^{1}$ What emerges is the central role of the church in providing a place of homeliness and security for many migrants. We argue that the 'Korean community' in Christchurch is as much the outcome of social exclusion, as it is of practices of community building by Koreans themselves.
\end{abstract}

\section{INTRODUCTION}

The majority of the families we interviewed for this project had left Korea with a great sense of hope about their new life in New Zealand, expecting to be welcomed and to be able to contribute to their new society, in short, to make a new home in New Zealand and become 'Kiwi Koreans. However, as the subsequent analysis of their interviews reveals, such aspirations have, for the most part, not been actualised. Hage argues that the project which engages migrants is "the building of the feeling of being "at home" in a new country (1997: 100). Home, for Hage, is an 'affective edifice' constituted out of feelings of 'security, familiarity, community and a sense of possibility' (1997:100), and it provides the base from which new migrants approach life in their new country. Being 'at home' involves the dual sense of 'finding a place' in the host society, and achieving a comfortable sense of one's own cultural identity. However, in a large number of cases for those whom we interviewed, initial optimism was tempered by the experience of living in Christchurch - a place in which they encountered differing degrees of harassment, discrimination and social 
exclusion. As such, in many cases Koreans have not come to feel 'at home'. As a result, the majority have turned to other Koreans for economic and social support, and the central site of this support are the Korean churches. In this way the perceived 'Korean community' is as much a product of exclusion by mainstream society as it is the outcome of a community building project by migrants themselves. In this paper we explore the kinds of social exclusion experienced by Korean migrants and the strategies they employ, both practically and interpretively, to achieve a sense of being at home in the face of such exclusion.

\section{METHODS}

This paper is based on is based on research conducted in Christchurch in early 2006 (Chang, Morris and Vokes, 2006). A total of thirty-six Korean immigrants, consisting of twelve men and twenty-four women, who ranged in age between twenty-four and sixty-eight years, were interviewed. They had been in New Zealand for an average of just over seven years, with dates of arrival ranging between one and twenty-three years before the date of the interviews. As such, the participants in the project constituted part of the 'new wave' of migration from East Asia outlined below.

Participants were recruited primarily through advertisements placed in local Korean media, in Korean. In addition, both the Korean Review newspaper, and the Christchurch Korea magazine, accompanied the advertisements with a feature on the project, based on interviews with the researchers. A smaller number of interviewees were recruited through existing contacts in the Korean community. Through these initial contacts, we gained more participants. We did not select participants on the grounds of age, gender, religion, or any other criteria. Instead, we endeavoured to interview all those who had expressed an interest in participating.

We explained to participants that we did not have a formal list of questions, but instead hoped that they would 'tell us their stories' and share their experiences of migration and settlement. In interviews we explored many aspects of the migration experience, from the initial decision to migrate, to the processes of 'home-building' in New Zealand. We endeavoured not to guide the conversation through our own questioning, but instead to allow participants to direct the conversation. Many of the interviews were conducted solely in English, while a few were conducted in Korean or in a mixture of Korean and English. In the latter case, Mrs. Suzana Chang - the only Korean speaker among the project researchers - acted as translator for other researchers present. Most in- 
terviews were conducted with individuals, although some included two people, generally spouses but also close friends. Most of the interviews were between one and two hours in length, and were recorded and later transcribed. Analysis took the form of migration narratives, as this was how interviews were structured, and via a thematic analysis of the content. Finally, this interview data was supplemented by participation in, and observation of, a number of Korean community and cultural events.

Across all of the interviews, a strong set of general themes emerged: in particular experiences of harassment and of the place of church in Korean life in Christchurch. Because participants were self-selected, it is impossible to know how widespread the experiences described are, and it is possible that some volunteered to talk precisely because of such experiences. However, informal feedback from participants suggests that the report found some resonance in the community.

\section{KOREANS IN NEW ZEALAND}

A number of international studies have noted the centrality of Korean churches in the social and cultural lives of Korean migrants (e.g. Cho 2005, Min 1992, Soo 1994) and some research has been carried out on the place of church in the lives of Pacific peoples in New Zealand (e.g. Anae 1998, Macpherson and Macpherson 2001, Tauleale'ausumai 2001). There is now a significant, and growing, body of work on East Asian migration to New Zealand (Bartley 2004, SROW 1979, Ip 2003, Ip and Murphy 2005, Johnson and Moloughney 2006, Butcher, Spoonley and Trlin 2006, Ho and Bedford 2006) but there is little that focuses specifically on Korean migrants. The research by sRow (1979) into the experiences of Asian migrants in Christchurch included Korean participants as did Lidgard's $(1996,1998)$ studies of East Asian migration and Ho, Goodwin, Bedford and Spragg's (1997) study on migrants in the workforce. These studies tend to be survey based, and provide broad outlines of the situation of migrant communities, with a few comments from participants. What these studies indicate is that migrants from a number of Asian countries find their desire to integrate into New Zealand society thwarted (sRow 1979: 5; Lidgard, 1996:35), and that in this circumstance church comes to play a critical social role (sRow 1979: 6, Lidgard 1996:26-27, 1998:36). What is missing from these studies is a detailed ethnographic account of how this process occurs, and of migrants' experiences of it. Koo's study of Korean migrants to Christchurch (2004) provides the most detailed, and relevant, comparative case. Similarly to our findings, Koo reports that migrants found employment opportunities limited (Koo 2004: 85), and 'show a tendency to spend time with only a few 
close Koreans and so relationships with New Zealanders are extremely confined' (Koo 2004: 83). In contrast to our findings, his research indicates that this is because of a lack of Korean desire to mingle: 'many Korean immigrants are indifferent to the New Zealand society and fail to build their identity as immigrants. As a consequence, the behaviours and attitudes of life that these immigrants show do not turn out to be so much different of people in Korea' (Koo 2004: 83). This difference is likely to reflect difference in experience among Korean migrants, but it may also be a reflection of differences in how participants were recruited, and, potentially, because of the different nationality of the researchers. As noted above, we suspect that some participants volunteered precisely because they wanted to tell their stories. Indeed, the aim of one woman appeared to be to ascertain the reasons for her experiences of harassment from a 'New Zealander'. Koreans, we were told, were concerned to 'save face' in front of other Koreans, and as such may have been unwilling to tell stories which intimated that their decision to migrate was problematic in any way.

Korean migrants form part of the wave of East Asian migration to New Zealand that began in the early 1990 s as a result of major changes in New Zealand's immigration laws which encouraged economic migrants. The reasoning behind this changing public policy was the view that a demographic mix of entrants would strengthen New Zealand's international economic competitiveness and 'enrich the multi-cultural social fabric of New Zealand society through the selection of new settlers principally on the strength of their potential personal contribution to the future well-being of New Zealand' (McKinnon 1996:45). These changes aimed to inaugurate a future in which 'the selection of new immigrants will be based on the criteria of personal merit without discrimination on grounds of race, national or ethnic origin, colour, sex or marital status, religion or ethical belief' (McKinnon 1996:46). The resulting legislation, the Immigration Act of 1987, embedded these principles by defining 'origin-neutral' categories of selection for potential new immigrants. Unlike previous immigration laws, these reforms favoured potential immigrants from East Asia, or at least did not discriminate against them. Furthermore, anecdotal evidence suggests a concomitant general 'softening' of official attitudes towards applications from East Asia. However, this 'softening' of attitudes was largely restricted to officialdom, and did not extend to general public opinion. Tracking surveys conducted since 1994 by AsiaNZ suggest that in terms of public attitudes towards Asian immigrants, the most negative attitudes have consistently been saved for immigrants from East Asia (Asia: NZ Foundation 2007; Kember 2002:4). 
Throughout the 1990s, the number of migrants entering New Zealand from East Asia rose sharply. At the end of 1991, 930 Koreans were registered as living in the country. At first, most of these new migrants settled in Auckland, but as numbers increased, new Korean migrants settled in Christchurch, Waikato and Wellington. Fifteen years later 30,792 people identified as being of Korean ethnicity in the 2006 Census (Statistics New Zealand 2007: 8), making them the tenth largest ethnic group in New Zealand. Because of their recent migration the Korean community has particular characteristics: $94 \%$ of all Koreans in the country were not born in New Zealand, and $87 \%$ have lived here for less than a decade. Further, in the 2001 census, $26.3 \%$ of all Koreans stated that they did not speak English (Statistics New Zealand, 2002). Partly as a result of this language barrier, the Korean community has experienced very high levels of unemployment. At $57 \%$ Koreans have one of the highest rates of unemployment in New Zealand, and the second lowest level of personal median income, at just \$5,300 p.a. (Department of Labour 2006). ${ }^{2}$ This is lower than the median income of even the Somali community, most of whom entered New Zealand on humanitarian grounds. In addition under-employment remained a problem. Having arrived in New Zealand on the 'general skills' stream, most of the new migrants were drawn from the Korean middle-classes, and had held senior managerial and technical positions in Korea. However few were able to secure comparable posts in New Zealand. Instead, they were more likely to find themselves working for small-scale businesses - grocery shops, restaurants, travel agencies - which existed largely to serve the Korean community itself.

A number of studies show that Korean migrants express a strong desire to participate in local community life and to 'join in with the things Kiwis do' (Lidgard, 1996: SROW, 1979:5) However many Korean migrants found this difficult to achieve. As one woman from Hong Kong in Lidgard's study commented, 'new immigrants don't really want to stick together but if they feel unwelcome they do' (1996:35). Despite an overwhelming desire by new migrants to develop friendships and contacts with other New Zealanders, more than half of new Korean migrants reported that even after eighteen months in the country, they had yet to make any friends or acquaintances outside of their own ethnic group (New Zealand Immigration Service 2004). After the same length of time in the country, Koreans were the least likely of any new migrant group in the country to have taken up membership of any social or sporting organization. For many, the experience of migration is one of isolation (Lidgard 1996:39).

However, one kind of organisation that Koreans do belong to in large numbers is churches. In 2001, more than half of all Korean immigrants in New Zealand 
claimed to be regular churchgoers, while an even larger percentage identified themselves as Christian. ${ }^{3}$ Most Koreans in Christchurch attend one of the city's dozen or so Korean churches, with a lesser number attending a 'Kiwi' church". Church is central to the experience of many new Korean migrants living in New Zealand and in coming to feel at home (Lidgard 1996, 1998; SROW 1979, Chang, Morris and Vokes, 2006). As well as meeting the spiritual needs of their congregations, churches are an important source of social support, and a key venue for meeting people and making friends. Indeed, for some, the social functions of church may be more significant than spiritual functions (Lidgard 1996:27; Chang, Morris and Vokes 2006). This centrality of church in social and economic life, we will suggest, can be understood as a response to the community's lack of integration into wider New Zealand society, in turn the outcome of social exclusion. It is to an in-depth discussion of the thematic evidence obtained from interviews with community members which supports our argument that we now turn.

\section{MIGRATING TO NEW ZEALAND}

All of the interviewees discussed the decision to leave Korea and migrate to another country as being the outcome of a number of push and pull factors - the stress of life in Korea in terms of the education system, work regimes and gendered family roles, and the promise of a more relaxed life in a Western country, with the additional benefits that accrue to those with an English education. For some migrants, New Zealand was one possible destination out of several (particularly Australia, the United States and Canada), with factors such as the exchange rate and the particularities of immigration policies proving the decisive factor. Others had chosen New Zealand specifically for its uncrowded, natural image and relaxed way of life. The key elements of the discourse about New Zealand were that it is clean and green, not overcrowded and very rural: 'there is nature here'. In particular, the availability of leisure time is often emphasized. Golf emerged as a key idiom through which the benefits of New Zealand vis-à-vis Korea were expressed. One man told us that the price of two games of golf in Korea is the same as an annual club fee in New Zealand. In this way New Zealand stands as the 'opposite of Korea', understood as urban, over-crowded, polluted and stressful.

All of the Koreans we spoke with had looked forward to becoming part of New Zealand society prior to leaving Korea. They had hoped and expected to meet and make friends with those whom they called 'Kiwis'. They expected that by virtue of having met the rigorous immigration criteria, by being financially secure, and ably demonstrating their respect for the value of education and the 
value they placed on hard work, that they would be welcomed into New Zealand, and would be able to participate fully in New Zealand society. However, many people found that this was not the case. Instead of being made welcome and being valued for their potential contribution, they experienced differing degrees of rejection across a variety of sites. We will now discuss these varieties of rejections in more detail.

\section{EMPLOYMENT}

Just as for Korean migrants in general, Koreans in Christchurch found it difficult to obtain what they considered to be appropriate employment. Koreans who migrate under the general skills system have high educational qualifications and considerable professional work experience-they are engineers, computer programmers, pilots and architects. Though they qualify to come to New Zealand in part because of their professional qualifications, they find that it is well nigh impossible to find jobs in New Zealand in their fields. One woman told us that she thought seventy percent of Koreans in Christchurch did not have jobs, and another said she would not recommend Christchurch to any Koreans even though it is a good place to live, because it is too hard to get a job here as a Korean'.

In part, this lack of employment opportunities reflects Christchurch's small size and lack of industry, but it is not just a matter of the availability of work in particular fields. 'Kiwi companies', people say, do not want to employ Koreans. Some Koreans say this is because their English is not good enough, and this is why they cannot get jobs. They expect that when their English improves, so will their job prospects. Others, however, say that Korean unemployment is the result of anti-Asian feeling, discrimination and racism. Several longerterm migrants pointed out that it is also very difficult for their children to find jobs here, even though they are fluent in English, have attended New Zealand schools and gained New Zealand qualifications.

As a result of their inability to obtain employment, people either obtain unskilled work such as taxi driving or factory work or gain employment in either small retail businesses that cater to the Korean community (restaurants, bakeries, Korean food supply shops, gift shops, travel agencies etc) or the kinds of businesses that commonly attract new migrants (dairies, fish and chip shops, photo processing shops etc.). We were told stories of doctors working as taxi drivers and a veterinarian working in retail. One woman, who has been unable to gain a job as a math's teacher even after achieving top marks in New Zealand teaching and math's qualifications, said, 'finally I dropped the idea 
of getting a job in New Zealand society. Instead I've just decided to... live off other Koreans', by which she means tutoring Korean students.

Koreans have come to form an economic enclave. In response to a suggestion by the interviewer that it must be difficult for a Korean who spoke no English to live in Christchurch, one woman replied: 'It's easy. It's not very difficult. Because Korean shops is everywhere, Korean people everywhere. If I don't get involved in Kiwi society, we need only little English to buy some ingredients from the supermarket, that's all.' Most Korean immigrants, she said, live Korean lives here just like they did in Korea.

\section{SOCIAL EXCLUSION}

Koreans also experienced social exclusion. Koreans easily met other Koreans through church and through existing networks of family and friends. 'It's so easy, you go to church and you meet everybody', said one person. There are now many Korean organizations in the city, and there seem to be enough Koreans now for most people to be able to develop friendships with likeminded people. However, establishing relationships with Kiwis ${ }^{5}$ proves to be much more challenging.

All of the Koreans we met wanted to know more Kiwis and were disappointed that they had not achieved this. 'I wanted to know exactly (how) New Zealand people live, you know?' said one person. Many made purposeful efforts to meet Kiwis. They joined Kiwi churches and sports clubs, became volunteers, and helped at their children's schools, and went to night classes: 'I $\operatorname{tr}[i e d] \mathrm{ev}$ erywhere, one woman said. The most common groups of Kiwis most Korean migrants got to know were their neighbours and the mothers of their children's school friends. One man told us that his family was lucky to get an 'amazing' landlord who 'feels like family.' Another woman told us that if she needed help or information she would knock on her neighbour's door. They were helpful and she was able to improve her English and knowledge of Kiwi society through talking with them. Almost all those with children who attended primary school in New Zealand said that they had made friends with the parents of their children's school friends. Mothers are sometimes invited to play-dates along with their children: 'my daughter and friend they play together and my daughter's friend's mother and I, you know, play together' These Kiwi mothers were very nice and taught her Kiwi customs like baking and making tea and coffee. One woman reported that since her son started school, 'I feel I'm so much involved in Kiwi society.' 
REJECTION

However, most people also experienced some form of rejection. One woman told us that she 'rather thought nice people would come to me to try to make friends with me but that didn't really happen.' She was frustrated at the time, but 'now I've sort of given up', she told us. Another took Spanish and Japanese night classes, thinking that the Kiwis who took them would be interested in other cultures and thus would be interested in knowing her. However, when she introduced herself by her English name, a Kiwi woman said 'You can't be called [her name], you're Asian', and she dropped out of the class.

Kiwis are polite and friendly enough people in general, we were told, but they do not want to get to know Koreans well. As one girl told us, the Kiwis at her high school were kind and friendly in class, but they never met up much outside of school. Others said it is hard to make Kiwi friends because New Zealanders already have their families and friends here, and that it is much easier to become friends with Koreans or migrants from other countries, because they too might be feeling lonely. One woman said that she feels isolation and alienation' from the wider community. She loves Christchurch but sometimes does not 'know very well about its people and what is going on here'. As people have not been able to make Kiwi friends, they have turned to the Korean community for social support.

\section{HARASSMENT}

In contrast to the findings of Butcher, Spoonley and Trlin (2006:7), ${ }^{6}$ almost all of the people we spoke to have experienced some form of harassment since arriving in Christchurch. Experiences ranged from verbal abuse to having things thrown at them. Verbal abuse of the 'go-back-where-you-came-from' variety is very common. One woman told us about the constant harassment she endured as she went on her daily walk. Every couple of days she would be harassed: 'they used their middle finger and used the F-word and...like Asian bitch, like that, those kind of things. Always are horrid, whenever I walk. This makes her feel 'miserable and frustrated.' One day a group of teenagers threw stones at her, one of them hitting her calf. She could not stand it anymore, so she turned back towards them and they ran away from her, into a house. She knocked and asked to see their parents, but they just 'yelled at me again the f-word, a lot of f-words.' She asked one of the boys why he had thrown a stone at her, and he replied, 'It's fucking funny.' She pointed out that she could die, and he said, 'yeah, you can, but its fucking funny'. She went home, but, she said, she could not stand it any more and so she went back to the house. This 
time the owner of the house came to the door. He had been on holiday and the boys had been friends of his daughter's. The daughter denied that anything had happened. She did not call the police, because other Korean women had told her that the police pretended to listen to their stories and then did nothing about them.

Another woman told us that she was driving home after picking her sons up from an after school activity, when someone threw an egg at her car. At first, she thought it might not be because she was Asian because it was dark, but she went back the next morning and discovered that there was a lamppost where the car was hit. Since the egg had hit the back window where her son had been sitting, rather than her window, she believes that the person had paused to see who was in the car first, and had only thrown the egg once it became clear she was Asian. She also reported an incident that happened to one of her friends: she had been walking down the street in the middle of the day when a car stopped and someone inside opened the door and threw water all over her. A former dairy owner also told us that teenagers would regularly throw eggs and stones through the front door. He found this very stressful, and it was one of the reasons he eventually sold the business and got a job in a Korean company.

We were told that it is mostly young people who harass Koreans, but not always. We were told of an incident in which a middle-aged man in a business suit, and driving a large, modern car, had signaled to a Korean woman in the street. The woman told us that because the car expensive, she had thought that he was going to ask her for directions or something of the sort. As it transpired, he actually wanted to tell her that she was the ugliest person he had ever seen. She also did not go to the police, even though her husband had wanted her to, because 'he didn't do anything harm- the outer scratch- there is no outer scratch, but, inside me, scratched a lot. I know I'm not a beauty. I know I'm ugly, but, I don't want to be convinced by him.'

\section{RESPONSES TO HARASSMENT}

Koreans respond to this sort of harassment in different ways. Some people questioned whether the motivations for this sort of harassment were primarily racial. These people argued that everyone gets harassed, and that young people will always 'pick on you about something. This perspective was generally held by the younger Koreans. One young woman said that bullies would bully anyone, and that other Koreans simply feel they are being discriminated against because their English is not very good. They might think 'oh, well, 
they don't understand me, that's why they're ignoring me' kind of stuff, but in truth maybe that's not the reason.' Another agreed that if someone harassed a Korean it was not necessarily because the Korean was Asian, but rather because the offender himself was a 'bad guy.' She said 'in Korea if you meet a bad person you just say, 'what's wrong with him? Forget it.' But in New Zealand, in New Zealand it's racism,. This woman went on to say that assuming such incidents were racist was racist in itself. A older woman said that if someone said something negative to her she would just think 'alright, he's a bit funny', whereas some of her Korean friends would get very offended because 'they feel like a stranger all the time, wherever they go.'

However, many interviewees regarded such harassment as an expression of anti-Asian sentiment. Most accounted for this in terms of individual ignorance by people of 'low education' and 'low class', regarding anti-Asian harassment as an individual, rather than a societal, attitude. As one woman said, such incidents are a result of 'an individual personality problem', adding that most Kiwis were very friendly and that there are bad people and good people everywhere. Another said, 'you always get that negative feeling coming from lower class. You get that everywhere'. On the other hand, others have come to regard New Zealand as a racist society. One woman told us that her sister cannot recommend Christchurch to students coming into New Zealand to study because 'they have racism.' She says of the majority of Kiwi High school students: 'They don't see us as a human being. They just see us as, ah, coloured, or ugly one.' A younger woman told us that she felt that New Zealand teenagers were envious of the money Korean students had to spend, and did not like them 'making noises' (i.e. speaking Korean) in their country.

Some Koreans blamed other Koreans for anti-Asian sentiment. They said that these others did not learn English and did not try to fit in, and therefore brought discrimination on themselves, and thereby onto the rest of the community. One man said that he thought that Koreans were not a respected ethnic minority in Christchurch because 'we haven't done anything, we haven't proved ourselves, we haven't integrated.' Another young man told us that Koreans should make more effort to follow New Zealand laws and customs. Asians, he said, completely ignored some rules, such as driving laws, and that when Koreans cook Asian food, the smell might be offensive to Kiwis. However, he added that if Asians are rude, people assume it is because they are Asian and that all Asians will act that way. For example, if Chinese students eat and talk during lectures, it is because they are Chinese, whereas if a Kiwi does the same thing it is put down to him being a rude individual. That, he said, is 'why we have to be extra careful.' 
Some Koreans blame themselves individually for the harassment they experience. They say that it is their fault that their English is 'not good enough', and they expect that when their English improves, they will have better encounters. One woman did report that she has experienced much less harassment since her English has improved, and since she has learnt to recognize what sort of situations to avoid. Her past experiences of harassment have become 'like a faded memory.' However, other migrants whose English has improved have not found there to be a corresponding improvement in how they are treated, and so have developed 'racist society' accounts of their experiences. A few said that the harassment they experienced was a lesson from God. They said that Korean society was very racist, and so they were learning a divinely-ordained lesson in humility.

As a result of these experiences of social exclusion Korean migrants have turned to their own community for support, which means, to a significant extent, church.

\section{KOREAN CHURCHES}

Korean Churches provide a ready-made social network, providing practical, economic and emotional support for migrants. Congregations provide social life outside of services, and churches organize many activities. There are weekly bible meetings, men's, women's and youth groups to join, and frequent lunches to attend. For example, the Korean Presbyterian Church cooks a Korean lunch every Sunday, which is especially welcome to Korean students without their families who cannot get homemade Korean food anywhere else. As a result, one man explained, the church is 'the centre of the world' for new migrants. In the words of one man: 'because a lot of Korean people go to church, those socalled new migrants will try to go to church as well. Because they feel relieved there'. One woman said: 'some people, you know, they just come to church to make friends, and you know, just to get information about New Zealand. It didn't mean they were ...Christian from Korea.'

Most Korean migrants chose to join Korean churches, because the congregations were all Korean, the Ministers were Korean, and services were conducted in the Korean language. They joined Korean churches because this was where they felt most at home. For many, the church provided a haven of Koreanness in an unfamiliar society. Korean churches provide a range of benefits beyond the spiritual, and many of the Koreans we interviewed acknowledged this. Churches provide important social networks. One man said that some migrants do not necessarily base their choice of church on questions of spiri- 
tuality or theology, so much as on the feeling of community they get from being a member of a certain church. Many churches have sports teams, which play against other churches or ethnic groups. Youth groups go on tramping trips, and church members teach young Koreans born in New Zealand to play traditional Korean games. Some churches have 'cell' groups, whereby the pastor connects a few families. These smaller groups then meet weekly at one another's houses to discuss the week's sermons and in this way get to know each other well.

Church networks also provide potentially significant economic benefits. People talked about gaining jobs through church networks, and gaining customers and clients for their businesses, as well as being a source of business opportunities. One woman told us that she had been rung up 'out of the blue' and offered a job. She later found out that this person had been at her mother's church and the people there had recommended her.

One woman told us that she felt that some Koreans changed religion mainly so that they could gain business contacts through churches, a practice criticised by those with stronger faith. She told us of a person who had converted more than once to facilitate such contacts: they had been a Buddhist in Korea, before becoming a Christian upon arrival in New Zealand, to later become a Catholic ${ }^{7}$. She had subsequently moved to Australia, where she had apparently changed religion again. When one woman was asked if her brother went to church, she responded: 'he better, if he wants to get Korean clients!'. This woman also claimed that her brother had not attended church prior to securing his present job. Another woman noted that practically, if a Korean wanted to run a business, the first thing he or she would need to do would be to go to a church in order to connect with more people. Another explained that business owners looking for employees felt more comfortable finding them amongst their own congregations, as this would ensure them to be 'faithful and trustworthy.' One man said that church was a good place to find cheap products and source materials and supplies for his business. Many people join larger, well-established churches when they first arrive, we were told, as they are able to provide more of this kind of support.

Churches also provide a site for the acquisition of status within the New Zealand Korean community. Pastors and church elders are held in high esteem. One woman noted that Korean migrants are all university graduates, and had significant social status in Korea, whereas in New Zealand they might not even have jobs, and so 'feel so little.' She claimed that this is why so many Koreans go to church, in order to gain social, as well as spiritual, comfort. 
KOREANS AND 'KIWI' CHURCHES

However, a small number of those we spoke to had deliberately chosen not to attend a Korean church, but to instead attend a 'Kiwi' church. They did this because they wanted to participate in and become integrated into New Zealand society, and saw joining a Kiwi church as one way of meeting Kiwis. Joining a Korean church, by contrast, would tie them into the Korean community. One woman who said that she does not have time to attend any church because of the pressures of running a business, told us that if she had time she would want to go to a Kiwi church. She said, 'If I want to get to know Korean people I can, but I'm hesitating. She wanted to first get to know New Zealanders and learn more about their culture: 'I cannot become a Kiwi but I want to understand the Kiwi people properly', she said. Mixing only with Koreans would militate against her becoming part of New Zealand society. People were welcomed by these churches, where they were often the only Koreans. One woman told us that her Kiwi church group is 'just like a family. Attendance at a Kiwi church is perceived by those who attend them as a sign of success - that their English is good enough, and that they are socially skilled enough to operate in Kiwi society.

One key reason that some prefer to attend a Kiwi church is a perception that Korean churches reproduce the very social hierarchies and pressures of the Korea they are trying to leave behind. One woman told us that she went to a Korean church at first, but soon discovered that 'I wasn't the right person to stay in Korean church, like I wasn't the right person to stay in Korea.' Kiwi churches were reported as being less hierarchical, as being less demanding in terms of time and money, and as requiring less conformity.

One woman who attends a Korean church said that Korean churches expected much more of their congregation than Kiwi churches did. When she went to a Kiwi church, they merely told her about the bible study group, rather than expecting her to attend its meetings as her own Korean church does. Korean churches also expect members to do church work: 'If I volunteer to do this work, then they add on another work. If you show your willingness, they just expect you to do more and more', she said. One man told us that Korean churches are more hierarchical than Kiwi ones: 'in Korean society, naturally, they have levels. Even church they come in.' He thought that some of this system had simply been transported into the Korean churches in New Zealand. By contrast, Kiwi pastors 'acted very humbly' and because of this his wife 'feels free' in Kiwi churches. 
One woman explained that in Korean churches people are judged by how much time they spend in the church, how much they can be seen to be praying, and how much work they do for the church. If you do not spend a lot of time worshipping and helping, you are seen to be not a good Christian. According to this same participant, in Korean cell groups, the hostess must provide food. In Kiwi cell groups, by comparison, people bring food if they want, and stay to help the hostess clean up if they have time, but no one is ever forced to do either. Furthermore, she felt that the Korean church forced her to join a cell group, and then forced her to open up about her life. When she did, they would say things like 'no, that's not right, you should do it this way.' In the Kiwi cell groups by contrast, they would 'just wait for me to open my heart by free will?' In this way, friendship could grow naturally. She said: 'I feel much free, and I feel freedom...I want to be willing next time. Because without freedom I could be rebellious-No, I don't want to do this, this time. I was always like that.' This woman said that individuals are respected in the West, but that if a person is different in Korea, they are regarded as strange. This is why she did not want to live there and chose not to go to a Korean church.

We were also told that there was competition amongst the Korean churches and each wanted to become bigger, so pastors would give sermons telling the congregation that if they gave the church ten percent of their income God would bless them. If you did not, He would not. How much money families donated was a matter of public knowledge, and even families on tight budgets would comply because they were made to feel guilty if they did not. Others reported that Korean churches are hotbeds of gossip. As the Korean community is small in Christchurch everyone knows everyone else's business. One man said that in these small societies people sometimes hurt each other, because 'we know too well.' One woman reported that since they had come to New Zealand her husband had changed, and had begun to acquire 'a Kiwi mind.' As a result, he feels more hard with Korean society' and has less tolerance with the fact that people are so interested in other people's private lives.

\section{KOREANS AND CHURCH NON-ATTENDANCE}

A third category of people are those who chose not to attend any church at all. In many ways their aims and experiences parallel those of Koreans who attend Kiwi churches in that their aim is to not become too involved in the Korean community. In part, this strategy reflects a perception concerning the social constraints such involvement would bring. In part, it reflects a desire to become more integrated into wider New Zealand society. 
One woman who came to New Zealand in her teens stopped going to church in her last years of high school. She said that because the community was so small, rumours spread very quickly, especially if they were bad ones. She was disturbed that people she did not know seemed to know her. Another woman who also does not belong to a church, said that once when two business partners fell out, the congregation and criticized their behaviour: 'I thought, oh, that's terrible, separation itself might be difficult for themselves, but how could other people criticize their business and their situation if they don't know very well about that'. She said that those things happened all the time: 'I heard a lot of different but actually same stories.' Today, she tries to stay away from the Korean community as far as possible. She recently went to a church event to support her friends and was disturbed because at the event she recognized many people whom she knew in business and education contexts: 'It's a kind of invasion into your privacy. I just want to know them in a proper place.'

Another woman told us that she had decided before she left Korea that she would not join a Korean church because she would then be unable to develop her English. She said 'I don't want to be stranger in New Zealand society. I'd like to get into the New Zealand society. If I stay in little Korean society, I will be always the little society. They are only strangers. They never mix into the main society.'

\section{CONCLUSION}

The Koreans to whom we spoke had moved to New Zealand in search of what they perceived to be a better, less 'stressful' life for their family, and a better future for their children. They wanted to escape from what they regarded as negative aspects of Korean society - crowdedness, pollution, social competition and undesirable work regimes. They came to New Zealand with the hope and intent of becoming Korean Kiwis, full participants in wider New Zealand society. However, for many, this dream has not been fully realized. While most enjoy and appreciate the more relaxed life in New Zealand, many have experienced rejection. A large number have been unable to find employment in the professional fields in which they have been trained, and have been forced to take unskilled jobs, many in Korean owned businesses that cater to the Korean community. Few have been able to make Kiwi friends, and almost all report incidents of harassment. Thus, the general feeling can be described as one of 'social exclusion', whereby Christchurch emerges as not a very homely place to be. And in this context, many of these new migrants have been able to find social support only amongst other Koreans. 
As a result of all this, many Koreans have turned to, or been forced back onto, the Korean community, and in particular, to the Church. For many Koreans the Korean churches provide the only economic, social and personal support available. While Korean churches provide considerable practical assistance to migrants, and are a site of homeliness and security in a new and unfamiliar environment, participation also means potential separation from wider society, which can lead to a predominantly Korean life in New Zealand. Korean church networks make it easier for migrants to make a living and to develop social networks, but participation in Korean churches also results in individuals being less likely to develop their own networks into the wider society. Participation in Kiwi churches means that people are more integrated into New Zealand society, which is what many claim to have left Korea for in the first place. This situation presents particular problems for Koreans who do not want to go to church, for either religious or social reasons, as it makes it much more difficult for them to meet other Koreans. One young woman who does not go to church said that young Koreans tend to be grouped by religion, and that she cannot really have close friendships with Christians because she cannot get into their community. Individuals such as this face potentially significant social isolation. What this means is that church, already an important part of many peoples' lives in Korea, has become the central institution of the Korean community in Christchurch, and for the majority of people with whom we spoke, it was within Korean churches that they were able to achieve a sense of self valued, a sense of social and community support, and ultimately, a feeling of 'being at home' in New Zealand.

Self appointed representatives of 'mainstream' New Zealand, as exemplified by New Zealand First deputy leader Peter Brown, regularly voice concern about the social consequences of rising Asian migration: 'Mr Brown has said the current immigration policy risks creating friction and dividing the country into mini-Asian societies. He said that if the open-door immigration policy continues, New Zealand could be inundated with people who do not want to integrate into society', (Radio New Zealand, 2008). What our research shows is that from a migrant perspective, the creation of a 'mini-Korean society' in Christchurch is an outcome of not a lack of desire to integrate, but of various processes of social exclusion. Thus, the onus for change lies not with the migrants themselves, but with the wider society within which they are trying to find a home. 
NOTES

1 We would like to acknowledge the support of the Families Commission/Komihana a Whanau who funded the research on which this paper is based.

2 The Department of Labour's figures exclude those who had enrolled in full-time education.

3 These figures are not surprising in the context of the global Korean Diaspora. While only $21 \%$ of all Koreans are Christian, most international migrants are members of the Korean 'middle classes', among whom Christianity is far more widespread (Min 1991).

4 'Korean churches' are defined as those which are run by and for Koreans, where services are conducted mostly in Korean, and where the Ministers and Pastors are from Korea. The largest of these churches in Christchurch is the Korean Presbyterian Church, followed by the Korean Catholic Church. However, there are also many other Korean churches, of varying size, including a Korean Buddhist temple. By contrast, churches which are not run by Koreans, which hold their services in English, and whose ministers are not Korean, are referred to by Koreans as 'Kiwi' churches.

5 Koreans commonly referred to New Zealanders as 'Kiwis' and to New Zealand things as 'Kiwi' things, so we have followed their usage of the term here.

6 Though Butcher et al did not interview Koreans, a Chinese person was included in their Christchurch focus group. The two focus groups consisted of four participants in each, each of whom came from a different country of origin (Butcher, Spoonley and Trlin, 2006:13).

7 'Christian' seems to refer to Protestant or Protestant-based denominations, and was regularly contrasted with Catholic in this way.

\section{REFERENCES}

Anae, M. 1998 'Fofoa-i-vao-'ese : the identity journeys of NZ-born Samoans', Unpublished Phd Thesis, University of Auckland.

Asia: NZ Foundation, 2007 Perceptions of Asia. http://www.asianz.org.nz/files/ Perceptions. 
Bartley, A. 2004 'Contemporary Asian Migration to New Zealand', in P. Spoonley, C. Macpherson and D. Pearson (eds) Tangata Tangata: the changing ethnic contours of New Zealand, Victoria, Thompson:157-174.

Butcher, A., P. Spoonley and A. Trlin, 2006 'Being Accepted: The Experience of Discrimination and Social Exclusion by Immigrants and Refugees in New Zealand.' Occasional Publication No. 13, New Settlers Programme, Massey University, Palmerston North.

Chang, S., C. Morris, C., R. Vokes and New Zealand Families Commission 2006 'Korean migrant families in Christchurch: expectations and experiences', Wellington: Families Commission.

Cho, K. 2005 'Religion in Diaspora: the transformation of Korean immigrant churches in global society', Unpublished M.A. thesis, University of Ottawa.

Department of Labour, 2006 'Skilled Migrants in New Zealand: A Study of Settlement Outcomes', Wellington: Department of Labour.

Hage, G., 1997 'At Home in the Entrails of the West: multiculturalism, ethnic food and migrant home-building, in H. Grace, G. Hage, L. Johnson, J. Longsworth and M. Symonds, Home/World: Space, Community and Marginality in Sydney's West, Annandale: Pluto Press: 99-153.

Ho, E. and R. Bedford, 2006 'The Chinese in Auckland: changing profiles in a more diverse society', in W. Li (ed) From urban enclave to ethnic suburb: new Asian communities in Pacific Rim countries, Honolulu: University of Hawai'i Press: 203-230.

Ho, E., Goodwin, J., Bedford, R. and Spragg, B. 1997 'Migrants in the Workforce: A Preliminary Comparison of the Experiences of Chinese and Korean Recent Immigrants in 1991 and 1996', Population Conference: Wellington.

Ip, M. 2003 Unfolding history, evolving identity: the Chinese in New Zealand, Auckland: Auckland University Press.

Ip, M. and N. Murphy 2005 Aliens at my table: Asians as New Zealanders see them, Auckland: Penguin Books.

Johnson, H.M. and Moloughney, B. 2006 Asia in the making of New Zealand, Auckland: Auckland University Press. 
Kember, J. 2002 'Asian Migration to New Zealand: A Changing Pattern', Address to Semyong University, Republic of Korea, 2 May 2002.

Koo, B.G. 2004 'Adaptation Process and the Mental Health of Korean Immigrants' in S. Tse, A. Thapliyal, S. Garg, S. Lim and M. Chatterji (eds), Inaugural International Asian Health Conference: Asian health and wellbeing, now and into the future, Auckland: University of Auckland, School of Population Health:79-90.

Lidgard, J. 1996 'East Asian migration to Aotearoa/New Zealand: perspectives of some new arrivals', Hamilton: Population Studies Centre, University of Waikato.

Lidgard, J. 1998 'Immigrants from Korea, Taiwan and Hong Kong in New Zealand in the mid-1990s: macro and micro perspectives', Hamilton: Population Studies Centre, University of Waikato.

McKinnon, M. 1996 'Immigrants and Citizens. New Zealanders and Asian Immigration in Historical Context', Wellington: Institute of Policy Studies Victoria University.

Macpherson, C. and Macpherson, L. A. 2001 'Evangelical Religion Among Pacific Islands Migrants: New Faiths or Brief Diversions?', Journal of Ritual Studies, 15: 27-37.

Min, P.G. 1992 'The Structure and Social Functions of Korean Immigrant Churches in the United States', International Migration Review, 26 (4):1370-1394.

New Zealand Immigration Service 2004 'Migrants' Experiences of New ZealandPilot Survey Report', Wellington: New Zealand Immigration Service.

Radio New Zealand, 2008 Brown Defends Comments on Asian Immigration. http://www.radionz.co.nz/news/latest/200804032043/12bdod65, downloaded $4 / 4 / 2008$.

Society for Research on Women in New Zealand (sRow) 1979 'Immigrant women: a survey of sixty-two immigrant women in Christchurch', Christchurch: Christchurch Branch of the Society for Research on Women in New Zealand. 
Soo, H.G. 1994 'An Overview of the Life of Koreans in Sydney and their Religious Activities', Korea Journal, 34: 67-76.

Statistics New Zealand, 2002 Census Snapshot: Cultural Diversity, Wellington: Statistics New Zealand.

Statistics New Zealand, 2007 Profile of New Zealander Responses, Ethnicity Question, 2006 Census. Wellington: Statistics New Zealand.

Taule'ale'ausumai, F. 2001 'New Religions, New Identities: the Changing Contours of Religious Commitment', in C. Macpherson, P. Spoonley and M. Anae (eds), Tangata o te Moana Nui: the Evolving Identities of Pacific Peoples in Aotearoa/New Zealand, Palmerston North: Dunmore Press. 